\title{
STUDY OF THE STATE OF SURFACE WATERS OF THE NORTHEAST CASPIAN SEA DURING DEVELOPMENT OF OIL FIELDS
}

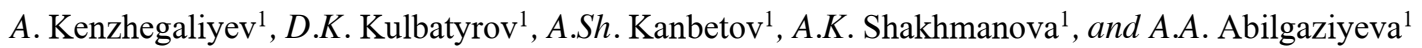 \\ ${ }^{1}$ Non-profit JSC «Atyrau Oil and Gas University named after S. Utebayev», Kazakhstan, Atyrau
}

\begin{abstract}
The relevance of the research is due to the fact that the Kashagan field has resumed oil and gas production, and up to this date more than 40 million tons of oil have been produced. In this regard, the study of the state of pollution of surface waters and its dynamics is relevant. This article is aimed at detecting the state of contamination with biogenic elements, oil products, phenol, synthetic surfactants and heavy metals. The leading approach to the study of this problem is State Standard 17.1.5.04-81; The seawater sampling procedure is carried out in accordance with ISO 5667-9: 1992 and ISO 5667-2. The article presents the results of research conducted in 2019 and the dynamics of pollution with pollutants in the area of the Kashagan, Kairan and Aktoty fields in the licensed territory. At the Kashagan field, samples were taken from 14 observation stations for the study. The fields of Kairan and Aktoty are currently preserved. In this regard, 2 observation stations were studied at each of these deposits and the results were compared with the results of the previous year. Based on the data obtained, it was revealed that biogenic elements remained at the same level and below the maximum permissible concentration for the entire study period. Comparison with last years' studies shows that in 2019, the concentration of biogenic elements was lower than 2018 . The content of oil products and synthetic surfactants for the study period was higher than in 2018, but lower than the MPC for the fisheries reservoir, and the phenol content was at the level of 2018 and exceeds the maximum permissible concentration by 3 times. Heavy metals for the entire study period were at the same level, with the exception of copper and iron, the concentration of which is higher than in 2018, but less than the MPC. The materials of the article are of practical value for scientists engaged in the study of the state of the inland seas, undergraduates, doctoral students.
\end{abstract}

\section{Introduction}

Before independence, the Caspian Sea was a source of biological resources for 4 states of the former USSR, especially valuable fish species, which were supplied to the world market. After the collapse of the Union, each of the independent republics intensively began search work on hydrocarbon resources. So Kazakhstan, since 1993, began to conduct intensive exploration work on hydrocarbon raw materials in the Kazakhstani sector of the Caspian Sea.

Authors of works [1-12] investigated the state of contamination of water column in the studied area with biogenic elements, oil products, phenol, synthetic surfactants and heavy metals. In works [13-14] the results of integrated monitoring work on the state of components of the marine environment are published.

\section{Object and methods of research}

The object of the study is the Kashagan, Kairan and Aktoty fields. Content of biogenic elements [15-19], petroleum products [20], phenols [21], SPAS [22] and heavy metals [23] was determined in accordance with State Standard.

\section{Results and discussions}

Studies were carried out in the licensed territory for three seasons, since the Northern Caspian Sea is covered with ice in winter, the average concentrations of the values of the investigated substances of each season are shown in tables and Figures 1-3. Also, the tables and figures show the average concentrations of the ingredient over the past 2018 and the MPC values for the fisheries reservoir.

Table 1. Average concentrations of biogenic elements by seasons of $2019, \mathrm{mg} / \mathrm{dm}^{3}$, [24-25].

\begin{tabular}{|l|c|c|c|c|c|}
\hline \multirow{2}{*}{ Field } & \multicolumn{4}{|c|}{ Nitrogen } & \multirow{2}{*}{$\begin{array}{c}\text { Phosphor } \\
\text { us }\end{array}$} \\
\cline { 2 - 5 } & ammonium & nitrite & nitrate & total & 0,002 \\
\cline { 1 - 4 } $\begin{array}{l}\text { Kashaga } \\
\text { n }\end{array}$ & 0,016 & 0,0016 & 0,016 & 0,1 & 0,1 \\
\hline Kairan & 0,016 & 0,0016 & 0,016 & 0,002 \\
\hline Aktoty & 0,016 & 0,0016 & 0,016 & 0,1 & 0,002 \\
\hline MPC & $\mathbf{0 , 3 9}$ & $\mathbf{0 , 0 2}$ & $\mathbf{9 , 1}$ & $\mathbf{2 , 0}$ & $\mathbf{0 , 0 0 0 1}$ \\
\hline
\end{tabular}




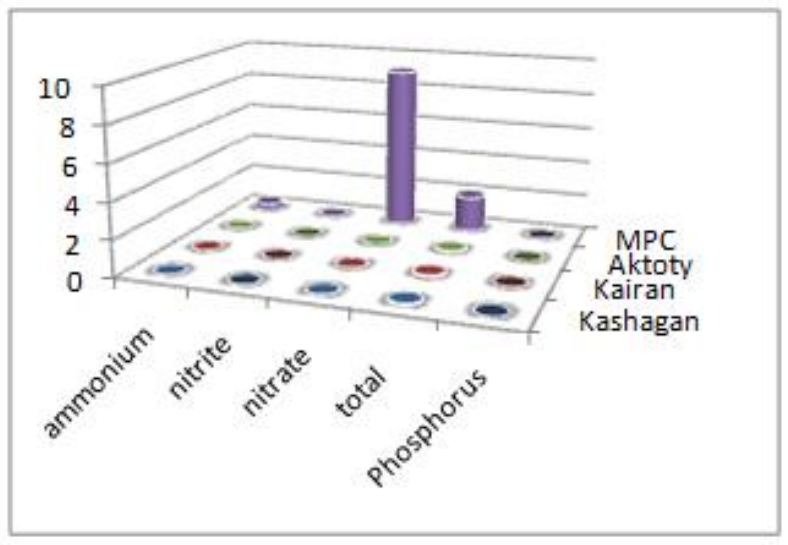

Fig. 1. Content of average concentrations of biogenic elements in sea water in the licensed areas of developed deposits.

The content of biogenic elements in seawater at all monitoring stations in 2019 was below the detection limit of analysis methods. At the indicated site in 2018 , the indicators of ammonium nitrogen were below the limit of detection of analysis methods everywhere. The average concentrations in the spring of nitrite nitrogen were $0.007 \mathrm{mg} / \mathrm{dm}^{3}$, nitrate nitrogen $0.3 \mathrm{mg} / \mathrm{dm}^{3}$, and total nitrogen $0.5 \mathrm{mg} / \mathrm{dm} 3$. Maximum total nitrogen values were observed at some stations in Eastern and Western Kashagan, where concentrations reached 0.7 $\mathrm{mg} / \mathrm{dm}^{3}$. In the autumn period, the values for the above substances were below the detection limit of the analysis methods. The total phosphorus concentrations were no more than $0.005 \mathrm{mg} / \mathrm{dm}^{3}$, except for areas around Islands $\mathrm{A}, \mathrm{D}$ and some stations where concentrations reached $0.07 \mathrm{mg} / \mathrm{dm}^{3}$.

The concentration of biogenic elements was below the limit of detection of analysis methods everywhere in 2019 at the Kairan field. In 2018, the indicators of spring average concentrations of nutrients had the following values: nitrite nitrogen - $0,005 \mathrm{mg} / \mathrm{dm}^{3}$, nitrate nitrogen $0.5 \mathrm{mg} / \mathrm{dm}^{3}$, total nitrogen - $0.6 \mathrm{mg} / \mathrm{dm}^{3}$, ammonium nitrogen and phosphorus total were below the detection limit. In autumn, on the contrary, the values for all substances decreased to the lower detection limit, and as for phosphorus, its concentration at station 2 increased to $0.009 \mathrm{mg} / \mathrm{dm}^{3}$.

A similar picture with biogenic substances developed in 2018 at the stations of the Aktoty field, where the concentrations were higher in the spring than in the fall. Concentration rates in all seasons of 2019 were below the detection limit of analysis methods.

Table 2. Average concentrations of hydrocarbons, phenol and synthetic surfactants in seawater by seasons $2019 \mathrm{mg} / \mathrm{dm} 3$, [24-25].

\begin{tabular}{|l|c|c|c|}
\hline Field & $\begin{array}{c}\text { Oil } \\
\text { products }\end{array}$ & Phenol & $\begin{array}{c}\text { synthetic } \\
\text { surfactants }\end{array}$ \\
\hline Kashagan & 0,033 & 0,0029 & 0,0066 \\
\hline Kairan & 0,06 & 0,005 & 0,005 \\
\hline Aktoty & 0,05 & 0,002 & 0,0066 \\
\hline MPC & $\mathbf{0 , 0 5}$ & $\mathbf{0 , 0 0 1}$ & $\mathbf{0 , 1}$ \\
\hline
\end{tabular}

The content of oil products at the Kashagan field decreases from spring to summer - by 2 times and amounted to $0.02 \mathrm{mg} / \mathrm{dm}^{3}$, by autumn it reaches the spring level. At the Kairan field in spring and summer, remaining at the same level, by autumn it rises to 0.12 $\mathrm{mg} / \mathrm{dm}^{3}$, i.e. to the level of 2.4 MPC. At the Aktoty field, as at the Kairan field, by autumn it reaches the level of 2.0 MPC.

The content of phenol at the Kashagan field for the investigated period from two MPC in spring and summer, by autumn, increases to almost $5 \mathrm{MPC}$, with a value of $0.0048 \mathrm{mg} / \mathrm{dm}^{3}$.

At the Kairan field in spring and summer, from 6 MPC by autumn, it decreased to 4 MPC, and at the Aktoty field from $1 \mathrm{MPC}$ in spring and summer, by autumn it increased to 6 MPC.

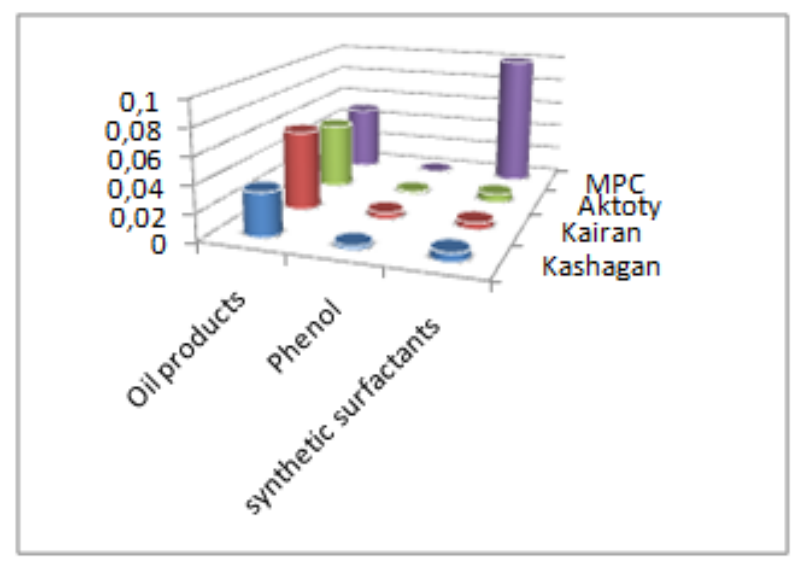

Fig. 2. Content of average concentrations of oil products, phenol and synthetic surfactants in seawater in the area of licensed areas of fields under development.

At the Kashagan field in the spring of 2019, the phenol concentration indicators for station 4 and 5 around island D were below the detection limit, the average for the remaining islands was $0.0032 \mathrm{mg} / \mathrm{dm}^{3}$. In summer, indicators were below the detection limit everywhere, except for island A (average value - 0.0089 $\mathrm{mg} / \mathrm{dm}^{3}$ ) and isolated cases around island $\mathrm{D}$, stations of licensed territories of Western and Eastern Kashagan. In autumn, the maximum values reached $0.013 \mathrm{mg} / \mathrm{dm}^{3}$ at station 1 of the licensed territory. In the fall of 2018, the maximum values were slightly higher $\left(0.014 \mathrm{mg} / \mathrm{dm}^{3}\right)$. The concentrations of oil products in spring and summer were also below the detection limit, except in isolated cases at D stations and some stations in the licensed area of the field. The maximum value of $1.14 \mathrm{mg} / \mathrm{dm}^{3}$ was recorded in the fall at the station in the area of island $\mathrm{A}$. While the average figures in the spring of 2018 did not exceed $0.04 \mathrm{mg} / \mathrm{dm}^{3}$, in the fall they significantly decreased, except for those at the stations of island $\mathrm{D}$, where the values increased to $0.11 \mathrm{mg} / \mathrm{dm}^{3}$.

At the Kairan field in 2019, oil product concentrations in the spring-summer period were below the detection limit. In autumn, the average concentrations of oil products were $0.14 \mathrm{mg} / \mathrm{dm} 3$. According to the results of analyses in 2018, the concentration of phenols and oilproducts was below the detection limit, except in spring, where the maximum values for oil products were $0.03 \mathrm{mg} / \mathrm{dm}^{3}$. 
Table 3.

\begin{tabular}{|l|c|c|c|c|c|c|c|}
\hline Field & $\mathrm{Cd}$ & $\mathrm{Cr}$ & $\mathrm{Cu}$ & $\mathrm{Fe}$ & $\mathrm{Ni}$ & $\mathrm{Pb}$ & $\mathrm{Zn}$ \\
\hline Kashagan & 0,00003 & 0,0003 & 0,013 & 0,02 & 0,0006 & 0,0003 & 0,0003 \\
\hline Kairan & 0,00003 & 0,0003 & 0,010 & 0,02 & 0,0003 & 0,0003 & 0,0003 \\
\hline Aktoty & 0,00003 & 0,0003 & 0,011 & 0,02 & 0,0003 & 0,0003 & 0,0003 \\
\hline MPC & $\mathbf{0 , 0 0 1}$ & $\mathbf{0 , 0 2}$ & $\mathbf{1 , 0}$ & $\mathbf{0 , 1}$ & $\mathbf{0 , 0 1}$ & $\mathbf{0 , 0 3}$ & $\mathbf{0 , 0 1}$ \\
\hline
\end{tabular}

At the Aktoty field, the concentrations of oil products in spring and summer, phenols - only in spring were below the limit of detection of analysis methods. In summer, phenol values were in the range of 0.0047 $0.0051 \mathrm{mg} / \mathrm{dm} 3$. In the fall of 2019 , the average values for oil products were $0.10 \mathrm{mg} / \mathrm{dm} 3$, and for phenols $0.0056 \mathrm{mg} / \mathrm{dm}^{3}$. In 2018 , values below the detection limit of analysis methods were universally recorded, except for oil products, the values of which were observed up to $0.03 \mathrm{mg} / \mathrm{dm} 3$ in the spring.

The average concentrations of heavy metals in seawater by seasons of $2019, \mathrm{mg} / \mathrm{dm}^{3}$, [24-25].

At the Kashagan field in the spring of 2019 , cadmium and lead concentrations were below the detection limit, except for one-time iron and nickel values at island A stations. In the summer of 2019, metal concentrations were below detection limits, except for copper. One-time indicators of nickel were noted in some stations of island A and the licensed territory. In the fall of 2019, copper and vanadium were found in the water of the deposit, the remaining heavy metals were below the detection limit.

High concentrations of total iron were observed only in spring 2018 at station 1 of island $\mathrm{D}$, where the concentration value reached $151.0 \mathrm{mg} / \mathrm{dm}^{3}$. In 2019 , in comparison with 2018 , changes in the concentrations of heavy metals were chaotic. It is worth noting that the concentration indicators for metals in the spring, summer and autumn of 2019 are almost the same, with the exception of chromium and iron in general, which had increased concentrations in the spring of 2019.

At the monitoring stations of the Kairan and Aktoty fields, as well as the adjacent licensed area, the concentrations of all heavy metals except copper, vanadium and nickel were below the detection limit of analysis methods. The last two elements showed onetime indicators of $0.0129 \mathrm{mg} / \mathrm{dm} 3$ at the station of the licensed territory of Aktoty - 1 in spring and 0.0136 $\mathrm{mg} / \mathrm{dm}^{3}$ at the Kairan station - 1 in summer, respectively. In 2019, for copper, the maximum indicators of 0.0159 $\mathrm{mg} / \mathrm{dm}^{3}$ were in the fall at the Kairan station - 3. In 2018, concentrations of heavy metals: aluminum, cadmium, mercury, lead during the year were below the detection limit of analysis methods. In spring, the results were below the detection limit in arsenic, vanadium, in autumn - in total iron. In spring, the average values of barium and zinc were 37.0 and $33.0 \mathrm{~g} / \mathrm{dm}^{3}$, respectively. The average concentrations of total chromium and nickel were between 14.4 and $17.03 \mathrm{~g} / \mathrm{dm}^{3}$. Minimum average copper concentrations did not rise above $4.05 \mathrm{~g} / \mathrm{dm}^{3}$. The maximum average concentrations of total iron did not exceed $64.67 \mathrm{~g} / \mathrm{dm}^{3}$. In autumn, the average values of the minimum nickel concentrations varied from 1.5 to 4.37 $\mathrm{g} / \mathrm{dm}^{3}$. High average concentrations (10.4 to $\left.47.3 \mathrm{~g} / \mathrm{dm}^{3}\right)$ were recorded for total chromium, copper, zinc.

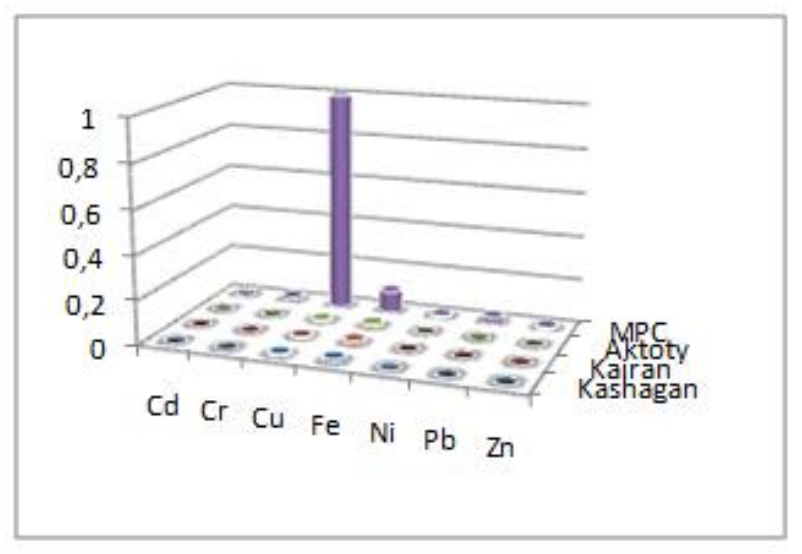

Fig. 3. Content of average concentrations of heavy metals in sea water in the licensed areas of developed deposits.

\section{Conclusions}

The biogenic content in seawater at all monitoring stations was below the detection limit of analysis methods in all seasons of 2019. In 2018, the indicators of ammonium nitrogen in spring and in the nitrogen group in autumn were below the limit of detection of analysis methods. Maximum values of total phosphorus concentrations at some stations reached 0.01-0.07 $\mathrm{mg} / \mathrm{dm}^{3}$.

Phenol concentrations in 2019 were in the range $0.0025-0.0303 \mathrm{mg} / \mathrm{dm}^{3}$. An increase in phenol concentration was observed in summer at Kalamkas field stations. However, it should be noted that in the Northern Caspian Sea there was previously instability of the background of phenols and high values of their concentrations. The values of oil products in springsummer periods were below the detection limit, except for isolated cases around Island D, the licensed territory of Kashagan, the maximum values for which did not exceed $0.17 \mathrm{mg} / \mathrm{dm}^{3}$. The average concentrations of oil products did not exceed $0.89 \mathrm{mg} / \mathrm{dm}^{3}$, the maximum value of $1.14 \mathrm{mg} / \mathrm{dm}^{3}$ was recorded at the station of island $\mathrm{A}$ in the autumn period. It is worth noting that hydrocarbons can flow into sea water as products of biodegradation, life activities of organisms.

The water condition was monitored for seven heavy metals. During the study period, the concentrations of lead, zinc, as well as in summer and autumn for other heavy metals, except copper and nickel, were below the limit of detection of analysis methods everywhere. 100\% presence in water samples was typical of copper. In 
general, the water area of the survey is characterized by initial (background) contamination with copper, nickel, due to natural conditions. Based on the results of environmental monitoring, it was established that the maximum concentrations of heavy metals in sea water were copper - $58.0 \mathrm{mg} / \mathrm{dm}^{3}$, iron total $-440.0 \mathrm{mg} / \mathrm{dm}^{3}$, nickel - $21.8 \mathrm{mg} / \mathrm{dm}^{3}$. The content of the remaining heavy metals as the maximum concentrations decreased was as following: chromium - $16.0 \mathrm{mg} / \mathrm{dm}^{3}$, cadmium $4.4 \mathrm{mg} / \mathrm{dm}^{3}$.

\section{References}

1. Monitoring of the environment of the North-East Caspian Sea during the development of oil fields [Electronic resource], Study results Agip KCO, 1993-2006, Almaty, 264 (2014) Available at: https://www.ncoc.kz/Documents/Environmental_ Monitoring _of_the_North-East_Caspian_Sea_ rus.pdf

2. Environmental Monitoring of the North-East Caspian Sea during Development of NCOC N.V. Oil Fields in the Period 2006-2016 [Electronic resource], Almaty: NCOC C.V., KAPE., 400 (2018) ISBN: 978-601-332-146-2 Available at: https://www.ncoc.kz/Documents/NCOC_full_eng .pdf

3. A. Kenzhegaliyev, Impact assessment of oil exploration works on the ecological state of the Caspian Sea shelf, Vestnik TarSU named after M.Kh. Dulati «Prirodopolzovanie i problemy antroposphery», 2, 93-96 (2010)

4. A. Kenzhegaliyev, Anthropogenic load of offshore oil prospecting works on the environment of the Caspian Sea and methods of its reduction (Almaty, 185, 2010)

5. A. Kenzhegaliyev, M.T. Cherdabayev, S.S. Orekeshov, Ecological condition of the Caspian Sea shelf during large-scale oil-prospecting work, Appendix to vestnik MANEB, S.P-Donetsk, 15 (4), 623 (2010)

6. A. Kenzhegaliyev, Hydrological and hydrochemical assessment of the North-Eastern Caspian Sea «Current problems of chemistry and methods of teaching chemistry», I Regional scientific-practical conference with the international participation, Elista, Publisher Kalm. Un-ta, 173 (2012)

7. A. Kenzhegaliyev, M.T. Cherdabayev, S.S. Orekeshov, E.Zh. Serikbayev, T.M. Suesinov, S.E. Kenzhegariyev, Ecological condition of water column around Kashagan field, Truby BGTU, Serial «Chemistry, technology of organic substances and biotechnology», 4 (2014)

8. A. Kenzhegaliyev, B.B. Orazbayev, S.Zh. Zhumagaliyev, D.A. Kenzhegaliyeva, Ecological condition in the area of island " $D$ " of the Kazakhstan sector of the Caspian Sea (Raleigh, North Carolina, USA, Lulu Press, 179, 2015)

9. A. Kenzhegaliyev, T.M. Suesinov, S.E. Kenzhegariyev, E.Zh. Serikbayev, K.K.
Sarsenov, (2015). States of contamination of the North-East Caspian Sea with toxic substances, Resource-reproducing, low-waste and environmental technologies for subsoil development: Materials of XIV International conference, Moscow, Russia, Bishkek (Kyrgyzstan), RUFN, 413 (2015)

10. A. Kenzhegaliyev, M.T. Cherdabayev, S.S. Orekeshov, T.M. Suesinov, S.E. Kenzhegariyev, State of pollution of surface water in the northeastern part of the Caspian Sea, Vestnik AIOG, 2, 36-39 (2017)

11. A. Kenzhegaliyev, M.T. Cherdabayev, S.S. Orekeshov, T.M. Suesinov, S.E. Kenzhegariyev, State of contamination of surface water in the area of oil structures of the Northern Caspian Sea, "Modern state and prospects for improving the ecology and safety of life in the Baikal region "-" Belye Nochi-2016 ": an addition to co. of articles of the International Scientific and Technical Conference, Irkutsk, Publushing IrSRTU, 99 (2016)

12. A. Kenzhegaliyev, M.T. Cherdabayev, S.S. Orekeshov, T.M. Suesinov, Materials of VI International scientific-practical conference «Problems of preservation of Caspian ecosystem in conditions of development of oil and gas fields», Astrakhan, Caspian SIFI, 240 (2017)

13. B.B. Orazbayev, S.Zh. Zhumagaliyev, D. Kenzhegaliyeva, State of contamination of water column around island «D» of Kashagan field, Collection of works of VIII Kazakhstani-Russian international scientific-practical conference «mathematical modelling scientific-technological and ecological issues oil and gas industry, Atyrau, 109-112 (2014)

14. A. Kenzhegaliyev, M.T. Cherdabayev, S.S. Orekeshov, E.Zh. Serikbayev, K.K. Sarsenov, Contamination of the Northeast Caspian Sea by biogenic element, Resource-reproducing, lowwaste and environmental technologies for subsoil development: Materials of XIV International conference, Moscow, Bishkek (Kyrgyzstan), RUFN, 413 (2015)

15. Ammonium nitrogen ST RK ISO 5664-2006 (2006)

16. Nitrite nitrogen ST RK 1963-2010 (2010)

17. Nitrate nitrogen ST RK ISO 7890-3-2006 (2006)

18. Total dissolved nitrogen ST RK ISO 5663-2007 (2007)

19. Total phosphor ST RK 2016-2010 (2010)

20. Total concentration of hydrocarbons GOST 31953-2012 (2012)

21. Phenol GOST 26449, 1-85, 25 (1987)

22. Synthetic surfactants ST RK 1983-2010 (2010)

23. Heavy metals ST RK -17294-2-2006 (2006)

24. Sea monitoring of influence, SR report (final), LLP Kazakhstanskoe Agenstvo Prikladnoi Ekologii, Almaty, 326 (2018)

25. Sea monitoring of influence, SR report (final), LLP «Kazakhstanskoe Agenstvo Prikladnoi Ekologii», Almaty, 444 (2019) 